\title{
New Technologies in Maritime Education and Training, Turkish Experiment
}

\author{
Oral Erdogan, Ergun Demirel \\ Maritime Faculty, Piri Reis University, Turkey
}

Copyright $\bigcirc 2017$ by authors, all rights reserved. Authors agree that this article remains permanently open access under the terms of the Creative Commons Attribution License 4.0 International License

\begin{abstract}
The aim of this study is to introduce new technologies and approaches in the maritime education and training (MET) and Turkish experiment / acquisitions / contributions including some analysis which may be helpful for the future studies on this subject. As an example of such an effort, Turkish experiment / contribution on seafaring officer education system is presented and discussed which supports to understand the problem areas and further assists to take the proper actions to facilitate the adaptation process. Each steps of achievement process is analyzed to realize the key issues which are the main sources of discrepancies and difficulties. The results of the discussions grouped and associated to formulate possible / probable solutions. After testing suitability, reliability and acceptability of solutions, some applicable course of actions are introduced. The overall results of this study may be used by MET planners and researcher who will make further studies on this issue.
\end{abstract}

Keywords Maritime Education and Training (MET), New Technologies, MET in Turkey, Vocational Education, Matching Academic and Vocational Education

\section{Introduction}

The ships are the biggest machines ever created by the human being. The new ships are huge, state of arts and fully automated. To handle such modern ships efficiently and safely, the maritime industry needs highly qualified seafarers in particular seafaring officers.

Since 1980s crewing is a significant problem for maritime industry. Many studies such as BIMCO ISF Manpower Report 2005, 2010 and 2016 proved that there is a significant lack of seafaring officers. BIMCO/ISF Manpower Report 2016 estimates the shortage of Seafaring officers is 97,000 at 2020 and 147,500 at 2025. This situation enforces the revision of the programme and their contents to prepare the seafaring officers also for their future roles and encourage the young people to attract maritime schools. The Germanischer Lloyd and Fraunhofer CML (2014) conducted a large scale study involving 100 ship management companies across the globe to find what they are doing to improve their operation and what they consider as best practices in the industry. The companies have explained that their biggest challenges of ship management in mid-term future in five areas; Crewing (88\%), Technical Management (62\%), Financial Management (50\%), Quality and Safety (27\%) and procurement (12\%).

Pourzanjani (2002) and Schroder (2004) state that the crewing problem does not consists of quantity but also quality. There are also severe shortages of well qualified seafarers at different levels of seniority.

To improve quality of the seafarers IMO (International Maritime Organization) started a study to establish international standards in early 1970s. IMO's STCW (Standards for Training, Certification and Watchkeeping) defines international recognized standards for crew on board. The competencies in the STCW mainly based on technical and management skills as well as long duration practical studies at sea training. The STCW is the main reference of the maritime education and training (MET).

A major change is made in the STCW in 2011 which is required changing of MET programmes. This change lead to the diversity of MET training courses, the existence and development of MET programs, co-operations between MET and shipping companies, competitiveness of students and trainees in different MET programs. The MET institutions should keep close watch for such (Yongxing and Ruan, 2009).

MET is a unique area which requires meeting international standards in addition to national vocational qualification requirements. The Lingua Franca of the maritime business is English and seafaring officers require sufficient English language skills. Demydenko (2012) states that 'Maritime English as a Global Language and Lingua Franca, Maritime English is unanimously thought of as a global language used at sea'. All these facts make the design and delivery of MET very complex and require detailed studies. To achieve this difficult job, the MET planners try to achieve the following objectives: 
- To ensure English language skills required for officers

- To deliver formative science (mathematics and natural science) for further academic and vocational subjects

- To balance engineering and management skills of the cadets which both are essential for seafaring officers

- To match academic and vocational education

- To match international and local standards

- To adopt the new improvement in the programme to meet the requirements of the maritime industry

- To conduct scientific studies for innovation and post graduate studies

\section{Method}

To introduce new technologies and approaches in the maritime education and training and Turkish experiment, the study is conducted in three steps. In the first step it is intended to understand the new technologies and approaches in the MET and impact of these improvements on the development of an effective system to provide qualified seafarers who are then eligible to operate the ships effectively and safely. The second steps covers analysis of Turkish experiment on seafaring officer education system which is a significant example to understand problem areas and action to be taken to facilitate the adaptation process. The achievement process will be discussed in this step and the key issues which are the main sources of discrepancies and difficulties are highlighted.

In the final step the findings of the second steps are categorized, grouped and with a further study made to formulate possible/probable solutions to be proposed. After evaluating and testing these solutions, applicable course of actions are recommended.

\section{New Technologies and Approaches in the MET}

MET institutes need to adopt new technologies and improvements in the education and technology field. They also need to develop and transfer of innovation in their area of interest. That is the reason why many international MET platforms have been established such as IMLA (International Maritime Lecturers Association), IAMU (International Association of Maritime Universities), METNET, GlobalMET, MariFuture etc.

As far as concerning new technologies and approaches in MET, the intention is not to mention namely but grouping them in accordance to functions achieved. These are:

- The excessive use of the simulators to reflect the real life conditions and applications which provides better understanding

- Highly structured and lecturer verified long duration sea training as a follow up for academic studies to prepare the cadets for shipboard duties
- Improvement of managerial skills of the cadets for their managerial roles in the future and enable to make risk assessment and management at sea

- Designing holistic education and training programmes to meet both vocational and academic requirements

- Improvement of IT (Information Technology) skills of the cadets to understand and operate state of art systems and safe use of automation on board

- Use of e-learning methods to facilitate the continuous education of the seafaring officers during their sea period

- Establishment of strong cooperation and coordination with maritime industry to improve the academic programme and quality of onboard training

- External evaluation and verification of the education to provide feedback and ensure the quality of the education

The mock up bridge and engine rooms, exactly as the same navigation and communication equipment; fully equipped laboratories facilitate the delivery of the courses and provide better understanding of the students. The simulators also facilitate adaptation of the students to real equipment and systems as well as their duties on board.

Computer assisted training provides benefits to student to review of the subject delivered in the classroom and self-assessment of their achievement as well as better evaluation opportunities for lecturers.

IT support allows students to get in touch with lecturers and tutors on-line. It is also important to connect the students and MET institutions during sea training to solve their problems.

The lifelong learning (LLL) is an essential part of modern life which provide the people further education opportunities. The e-learning presents a great education and training opportunity for seafarers who are thousand miles away from the shore facilities. Nowadays there are many MET institutions providing e-learning for seafarers including postgraduate studies.

Effective use of the results of Port State Controls (PSC) and establishment of permanent validation/evaluation organs such as EMSA (European Union maritime Safety Agency) provide an excellent quality assurance opportunity for MET institutions.

The globalization makes the world like a small village. The shipping business is a worldwide business which requires full application of the international arrangements. In order to survive in competitive and challenging shipping business, all respective parties should meet golden standards not contented with minimum. There is no chance to be successful without qualified staff on board the ships. The MET is a key element to ensure the quality in shipping. In order to ensure the quality in the MET, the only way is the continuous improvement of the system with development and transfer of innovation following and adopting the new technologies. 


\section{Turkish Experiment}

\subsection{Improvement of Turkish Shipping Industry}

In 1980, the shipping industry was the beginning of the dark days and second-hand ship sales started with very low prices. The Turkish Chamber of Shipping was founded in 1981 and it became an important tool to organize private shipping sector. The newly established Under-secretariats of Maritime Affairs directly reporting to Prime Ministry assumed maritime administration functions. The Following year the government published a law concerning "Improvement of the Merchant Fleet and Incitement of Shipbuilding Industry" which has provided ship finance for the ship owners up to 90 percent and guarantee for the freight (Turkish Government, 1982). Many new shipping companies have been established. This incitement allowed the ship owners to buy mainly second-hand ships and the tonnage of the fleet suddenly increased to 5.123.888 DWT in 1989.

The beginning of the third millennium was a golden era for Turkish shipping. The increasing freight rates until 2008 encouraged the ship owners to enhance and renew their fleet. Old ships have been decommissioned, scrapped or sold and subsequently new, modern and bigger ships have entered service. The same efforts have been spent to improve shipyards and ports. Most importantly private sector and government agreed to apply higher standards as required in the new world order.

The financial turmoil in the 2008 has created a negative impact on the shipping industry. The sector has been badly influenced from the crisis but achieved somewhat to survive. At the end of the year 2013 the available figure of the total number of vessels over 1000 GT that Turkish flagged fleet had, was 641. That corresponds to a capacity of transportation reaching to 9.1 million DWT. Considering 21 million DWT ships operating under other flags; the total amount of the ships owned by Turkish ship-owners reaches 30.1 million DWT. This value is actually, ranking Turkey $13^{\text {th }}$, among the countries which are known to be the world's largest commercial fleet (IMEAK, 2014).

\subsection{Initiative to Improve MET in Turkey}

Having high-cost, brand new ships, Turkish ship-owners become more anxious about the quality of crew particularly officer ranks and commenced revisiting the quality of manning issue; this issue also became a concern of the government authorities. The new posture of the fleet suddenly attracted attention of all respective parties on crew quality in particular training became an important issue. The Chamber of Shipping, for some time now has been interested in seafarer's training as early as 1990. To respond the existing and future requirements of the shipping industry, the Turkish maritime industry improved a new strategy to improve MET in Turkey. This strategy based on the following principals:

- To provide full support to Maritime Education and Training in addition the government efforts

- Aiming to reach golden standards beyond the STCW's minimum standards to have qualified manpower for the merchant fleet

- Establishment of close cooperation between maritime industry, maritime administration and MET institutes

- Increase the number of qualified seafarers in support of both national and world fleet

In order to achieve this strategy TUDEV (Turkish Maritime Education Foundation) is established in1993. TUDEV started to support all levels of MET institutions by providing equipment and direct financial support. In 1995 TUDEV established the Institute of Maritime Studies to graduate unlimited officers for the merchant fleet between 2000 and 2011. In parallel to this activation TUDEV attempted a new initiative to establish a maritime university. The Piri Reis University (PRU) named after famous Turkish Admiral and cartographer, established in 2008. The aim of the PRU is beyond a center for seafaring officers. The Engineering Faculty and Faculty of Economics and Administrative Sciences of PRU is now conducting graduate and postgraduate education, and further studies to fulfill other requirements of maritime industry.

The international cooperation is the most appropriate manner to improve quality of the education and training by the way of transfer of innovation and awareness of best practices in the other parts of the world.

TUDEV established a strategy to achieve an effective international cooperation in 2003. The application of this multi-purpose cooperation is introduced in the Figure-1. 


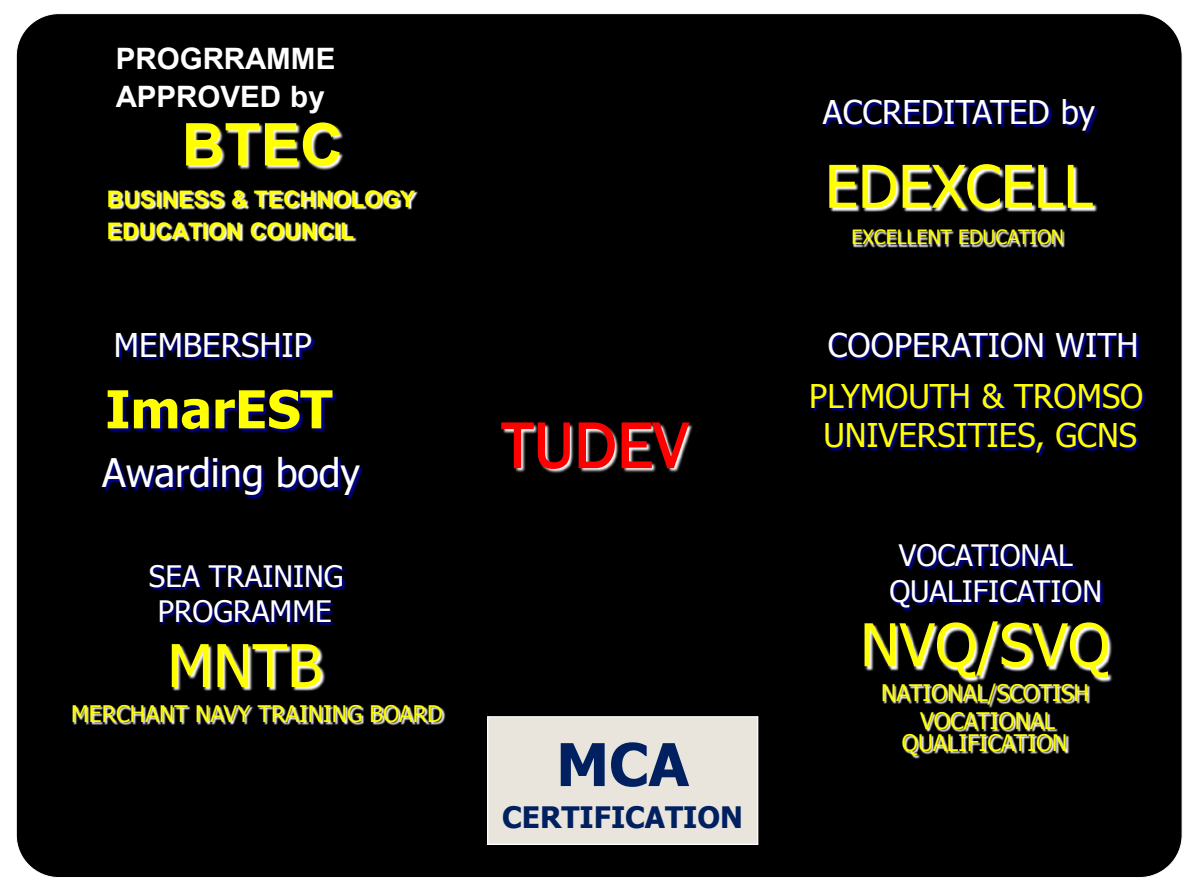

Figure 1. International Cooperation of TUDEV

The main objectives of this cooperation are as follows:

- Cooperation with internationally recognized accreditation and awarding organizations

- Improvement of academic programmes in cooperation with well recognized MET institutions.

As a part of this strategy the following achievements are succeeded:

- The HND Navigation and Marine Engineering programmes are adopted from United Kingdom

- $\quad$ The quality of the sea training improved adopting best practices

- $\quad$ Close cooperation with British awarding bodies such as MCA (Maritime and Coast Guard Agency) and ImarEST (Institute of Maritime Engineering, Science and Technology) established

- Quality Assurance is ensured having accreditation by internationally recognized Edexcel.

- Cadets get benefit from European Union Mobility programmes and sent to Plymouth University for Top-up programmes and Glasgow Collage of Nautical Studies for Post-HND programmes

- A long duration EU Project is initiated to improve education system, namely SoS (Safety at Sea)

- $\quad$ TUDEV become a well-known partner for many MET related European Union projects

\subsection{Piri Reis University Underway}

All these experiment have been transferred to the Piri Reis University. The Piri Reis University has more improved facilities, teaching staffs and state of art teaching aids in comparison with TUDEV Institute of Maritime Studies.
Today PRU is in close cooperation with other MET institutions and partner for many European Union (EU) and national projects. The international relations have been improved using European Union wide ERASMUS student and staff exchange programmes and mutual cooperation agreements are signed with many and faculties in the European area, Russia, Ukraine and China. PRU is represented in famous MET such as IMLA (International Maritime Lecturers Association) and IAMU (International Association of Maritime Universities) and leading/participating regional MET activities.

Now PRU is providing sea training with two training ships each has 250 cadets capacity for his students as well as other MET institutions in Turkey and regional countries.

Turkey has assumed EMSA (European Maritime Safety Agency) inspection on voluntary basis to ensure the quality of its maritime administration system. As a part of this program PRU has been inspected by EMSA and passed which proved that we are on correct track.

\section{Discussion}

The internet facilitates communications between the colloquies in distant countries. The lowering cost of air transportation eased to visit partners in the different countries. These improvements facilitated international cooperation and information transfer. European Union initiated projects facilitated the cooperation between the countries. DOI (Development of Innovation) and TOI (Transfer of Innovation) projects supported the research activities and transfer of innovations and best practices between the European Countries. 


\subsection{International Projects}

The common aim is to improve better education systems for World maritime community. Taking advantage of the opportunities offered us by technology and using advanced coordination techniques we can achieve it. Joint projects developed so far will be a good example for the future activities of which should we get benefit (Ziarati \& Demirel, 2011).

Nowadays participation to MET related EU projects is strongly proposed to improve programmes. The followings are the examples to assist the improvement of the programmes by transfer of innovation and best practices in the other countries:

- Improvement of a unified MET system for EU area (UniMET Project).

- Matching vocational and academic education and training programmes and ECVET versus ECTS (Be-TWIN Project).

- Matching the academic programmes of the MET institutions to facilitate student and lecturers exchange programmes (DECOMAR Project)

- Establishment of a Maritime Network of Education for Development of the maritime culture (MARINE Project)

- Introducing e-learning program for GMDSS(e-GMDSS)

It is approved that the international projects are more feasible than in-house studies. These projects create synergy and a platform for transfer of knowledge and innovations. A project which creates an innovative approach will be valuable not only for participants but also for all MET community. The joint projects developed so far will be good examples for the future activities from which we will benefit greatly (Demirel, 2013). These projects provide perfect platforms for development and transfer of innovation as well as establishing a common understanding and application.

\subsection{The New Roles of the Universities}

The mission and roles of the universities have been changed in the $21^{\text {st }}$ century. The research became a significant mission for the universities. The relations with community became a social responsibility for the universities. Now it is the time to improvement of the organization and management systems of maritime universities to balance teaching, research and community support functions.

The universities are also a part of the Lifelong Learning programmes. They need to empower the continuous education centers. This needs improvement e-learning, provision of special professional courses and certificate programmes to meet the requirement of related business sectors.

However, the government support for higher education is decreasing gradually (Zade et al, 2002). The universities should improve new sources to survive. Most importantly they should create an effective and internationally recognized education system which provides graduates better job opportunities.

\subsection{The Quality Assurance}

The Total Quality Management (TQM) system is the common tool to ensure the quality. TQM provides essential feedback to improve the quality of procedures and process applied. In particular Quality Assurance provided by recognized external authorities play an important role to define corrective actions to reach the commonly accepted standards. The external verification and a continuous feedback support are required to ensure quality of MET system. This will provide a reliable support to continue to improvement of the system.

\subsection{Improvement of Teaching Methods}

The classical teaching methods is about to come an end. The teaching methods may include class participation, demonstration, recitation, memorization, or combinations of these. The choice of teaching method or methods to be used depends largely on the information or skill that is being taught, and it may also be influenced by the aptitude and enthusiasm of the students. Creation of new teaching methods will facilitate delivery of the knowledge using all available assets. The MET education may be improved by establishing an effective link through classroom teaching, use of stand- alone computers, simulators and distance learning tools.

\subsection{Course of Actions}

Innovation in MET has been discussed in The IMLA 19 Conference conducted in 2010 at Shanghai/China. A paper has been presented by TUDEV/Piri Reis University to introduce lessons learned from Turkish experiment (Ziarati et al, 2010). In the light of Turkish experiment the following course of actions are deemed applicable for all MET institutions:

- Seek suitable partners for cooperation

- Form consortiums to facilitate cooperation and collaboration

- Seek support from international and national bodies

- Conduct serious research into identified problems facing the industry to understand the main issues and measures should be taken

- Develop serious proposals to meet the requirements

- Develop and motivate staff to conduct research on maritime industry

- Publish papers in refereed conferences and journals for information exchange

This course of actions have already been exercised and achieved. So we assume that all are suitable, reliable and acceptable.

Technology improves so rapidly which enforce us to make quick transformation in our education systems as it has 
happened in the other fields of contemporary business. McComb (2014) explains that situation with his statement; 'Transformation is an era, not an event'. As it has been happened in the other fields, MET institutions also require changing their organization, systems, programmes, delivery methods on a dynamic basis.

\section{Conclusions}

The shipping is now a high profile international business which has adapted the new technology and good practices in its management and operations. The structure of competition approach in the shipping industry has changed. Cooperation between government and ship-owners to create innovative and flexible strategies to meet the differential market requirements is vital in such a challenging world.

Major part of the world foreign trade is realized by maritime transportation. If the vision of a nation is to become a significant maritime country fleet, all aspects of the existing and future fleet requirements should to be considered.

Availability of qualified seafarers is a key element of shipping today which is of interest to all countries due to unbalanced supply and demand situation. The growing fleet means growing recruitment problem. All maritime players in countries need to improve the situation and to solve the requirement for qualified seafarers which is directly related to maritime education and training system.

The MET is dynamic field needs to have continuous review and update process supported with transfer of technology and innovation. In the light of previous experiment and future strategies, the following course of actions is proposed:

- Continuing the international cooperation and collaborations in particular regional cooperation which is more easy to establish and sharing mostly similar objectives

- Full support of Maritime Industry for MET is inevitable for success

- The technology transfer is essential to improve the MET

- Development and transfer of innovation is required for achieving quality

- Participation to international MET platforms are important to realize the new requirements and following improvement

- Not minimum but golden standards should be targeted to ensure safety at sea by the way of development of education system

- Close cooperation and collaboration between MET institutes and maritime industry is essential to satisfy expectations of the economy

- The MET institutions should rearrange their organization and management systems to support the research requirements of the maritime industry
- The creation of synergy is required for Combining vocational and academic and vocational education

- External Verification and establishment of a perfect feedback system are necessary to ensure quality

The common aim is to improve better education systems for seafarers to ensure safety and security at sea. The new opportunities offered us by technology and using advanced coordination methods we can improve the quality of MET worldwide. International platforms which host large number of the MET experts create a favorable environment to initiate or launch international projects to improve the quality of maritime education and training.

\section{REFERENCES}

[1] BIMCO/ISF, (2010). Manpower Report, The global supply and demand for seafarers in 2015, Bagsværd, Denmark

[2] Demirel E., (2013). Organizing International Cooperation for Maritime Education and Training to Improve the Quality, Proceeding of International Conference on Quality in Higher Education, 10-12 October 2013, Sakarya, Turkey 595-603

[3] Demydenko N., (2012). Teaching Maritime English: A Linguistic Approach, Journal of Shipping and Ocean Engineering 2 (2012) 249-254

[4] Fraunhofer CML and GL, (2014). Best Practice Ship Management Study 2013, GL Maritime Software Product, Hamburg OE845-2013-04-01 p. 2, 6

[5] IMEAK Chamber of Shipping, (2014). Maritime Sector Report 2013, Istanbul ISBN 978-9944-60-706-3

[6] McComb W. L.,(2014). Transformation is an era, not an event, Harvard Business Review, April 2014

[7] Pourzanjani et al, (2002). Maritime Education and Training (MET) in the European Union: How Can Maritime Administrations Support MET, Vol.2, No. 2 IAMU Journal, December 2002

[8] Schröder et al, (2002). 'The Thematic Network on Maritime Education, Training Mobility of Seafarers (METNET): The Final Outcomes', Vol. 3, No. 1, June 2002

[9] Turkish Government, (1982). Law No: 2581, Improvement of the Merchant Fleet and Incitement of Shipbuilding Industry, Statutory Gazette dated 21 January 1982 No: 17581, Ankara

[10] Yongxing, J., and Ruan, W., (2009). Understanding of the Impacts of the International Maritime Conventions and Rules upon Maritime Education and Training and the Strategies there of, IMLA 18 (2009) Conference Proceedings, Ghana

[11] Zade et al, (2002). Maritime Education and Training (MET) in the European Union: How Can Maritime Administrations Support MET, Vol.2, No. 2 IAMU Journal, December 2002

[12] Ziarati R., Demirel E., Albayrak T., (2010). Innovation in Maritime Education and Training, IMLA 19 Conference Proceedings, 20-23 October 2010, Shanghai, China

[13] Ziarati R. and Demirel E., (2011). International Cooperation for Maritime Education and Training, IMLA 20 Conference Proceedings, 28 September-1 October 2011, Opatija, Croatia 